$\mathrm{T}_{1}$ 浸潤性乳癌非生娭例の検討

一生検例との比較検討を中心に一

帝京大学医学部第 1 外科

○大塚美幸, 浅越辰男, 花谷勇治, 根本明久,

蓮見直彦, 関根

勝, 高見 博, 四方淳一

【目的，対象】1978年 8 月より12年 5 ケ月間に経験 した原発乳㾇290例のうち，T1浸閏㾔68症例(23.4\%) を検索対象として, 非生検例と生検例について比較検 討を行なった。【結果】原発乳㾇290例中 $\mathrm{T} 1=77$ 例（ 非浸潤癌 9 例を含む) で，T1浸閵癌68例中確定診断 するために生検が必要であった症例は52例 (76.5\%), 非生検例は16例（23.5\%)であった。非生検浸潤癌は生 検例之比較して70歳以上の高齢者, 体重比 $+11 \%$ 以上 の肥満者が多く，腫痀径は $16 m$ m上のものが75\%を占 めていた。診断の根拠となったのは, 触診での表面不 整・皮成宿凹・可動性不良, 超音波断層写真上の分縁 不整・内部エコーが粗く強く不均一な所見で, 乳房撮 影写真では陰影の存在・スピクラ・敞小石灰化の所見 であった。病理組織学的には非生検例は乳頭腺管癌と 硬痹が多く，生検例は乳頭腺管癌が多い傾向におった。 又, 非生検例は生検例之比較して低分化で細胞密度か 高く脂肪織浸潤陽性、眽管侵㬏陽性,リンパ節転移陽 性例が多い傾向にあった。

292 当科における乳腺外来手術の現況

大阪市立大学医学部第 2 外科

O中谷守一, 森本 健, 木下博明

大阪市立大学第二外科において平成 2 年 1 月から 12 月に 実施されたドリル生検 37 例を除く同所麻酔下外来手術 181 例中，乳眿手術は 107 例 (59.1\%) を占めた。男女比は男 3 対女 104 で, 年龄は最少 14 才, 最高88才で平均 40.6 才で あった。手術法は乳腺半切除術 1 例, 切除生検術 88 例, 区域乳管切除術 11 例, 人工材料の交换や拘縮被膜切離 術など人工乳房に関する手術 7 例であった。平均手術時間 は切除生検術 $42.2 \pm 19.9$ 分, 区域乳管切除術 $53.6 \pm 18.7$ 分, 人工乳房に関する手術 $50.7 \pm 35.2$ 分であった。租䅧別 には線維腺腫 43 例 $(40.1 \%)$, 乳腺症 18 例 ( $16.8 \%)$, 釈管 内乳頭腫 11 例 $(10.2 \%)$, 釉癌 9 例 (8.4\%), 女性化乳房 3 例 (2.8\%)，その他 23 例 (21.5\%) であった。また平均手 術時間は乳癌 $58.9 \pm 13.9$ 分, 乳腺症 $52.5 \pm 27.1$ 分, 釈管 内乳頭腫 43.6 \pm 16.5 分, 線維腺腫 $38.6 \pm 14.3$ 分, 女性化乳 房 $33.3 \pm 9.5$ 分である。とてろで 60 分以上の手術時間を要 した例は 16 例で, 術式別には切除生検術 10 例, 区域乳 管切除術 3 例, 人工乳房に関す万手術 3 例で, 組織別に は乳癌, 乳腺症, 乳管内乳頭腫が各 3 例, 線維腺腫 4 例であった。人工乳房に関する手術は外来手術の中で 乳癌とともに長時間を要する頻度が高かった。
293

乳癌におけるDSA と組織型との関連に

ついて-Time Density Curveの解析から-

東京女子医科大学付属第二病院外科, 同放射線科・

○渡辺 修, 若賀駿介, 清水忠夫, 飯田富雄, 今村 洋, 蒔田益次郎，小林浩司，木下 淳, 梶原哲郎，山田隆之゙

【はじめに】釉癌の経静脈的Digital Subtraction Angiography (IV-DSA) と組織型との関連についてT Time Density Curve (TDC)を解析することにより検討した。 【対象】対象は，腫富径 $5 \mathrm{~cm}$ 以下の原発性乳癌例 (乳頭 腺管癌 9 例, 充実腺管癌 12 例, 硬癌 9 例 ) である。 【方法】肘静脈に16Gエラスター針を留置。イオパミロン $40 \mathrm{~m} \ell$ と生食 $40 \mathrm{~m} \ell$ の二層性溶液を $15 \sim 16 \mathrm{~m} / \mathrm{sec}$ 自動注入し 层影。腫場濃染のTDC とその微分曲線を作成し最大濃 度值，微分最大值及びその所要時間を算出。また， TDCをS字型，直線型，ステップ型の3型に分類した。 【結果・結論】乳頭腺管癌は, 最大濃度值・最大微分 值が低值であり, 腫瘍内血管量か乏しいことが示㖫され た。TDCパターンでは特に傾向はなかった。充実腺管 癌は, 最大濃度值が硬癌とほほ等しく腫瘍内血管量も 同程度と考えられた。また，最大微分値までの時間か やや長く，TDCパターンではS字型か多かった。硬癌は， 最大濃度値は充実腺管癌とほほ等しいか，最大濃度ま での時間か長く，TDCパターンでは直線型が多かった。

294 超音波上腫瘦像描出不能乳癌について 社保船棈中央病院外科

○永野耕士、山野 元、武藤高明、吳 正信、 正岡 博、山口聖一

超音波診断上、最も重要なのは畽㾺像 (tumor echo) の描出と思われるか、、昭和57.1 - 平成 2.10 女子超音波施 行乳癌手術症例 444 例において、明らかにTumor echo を描出できなかった 31 例 $(7.0 \%)$ につき㭘討した。臨 床病期 腫唯 (T) より見ると（Tisを含む）、T0 8例、 T1a 11 例、T2a 7 例、T3a 5 例。病理的には非漫潤癌 17 例中 4 例 $(23.5 \%$ )、钽小管外浸潤癌（管内進展型を含 む) 22 例中 8 例 $(36.4 \%)$ 、浸潤癌 405 例中 19 例 $(4.7$

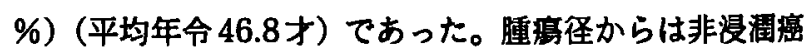
は $0.5 \mathrm{~cm} \sim 3.0 \mathrm{~cm}(1.7 \pm 1.1 \mathrm{~cm})$ 、微小管外浸清密 0.9 $\sim 7.0 \mathrm{~cm}(3.7 \pm 2.3 \mathrm{~cm}) 、$ 浸润癌 $0.5 \sim 5.2 \mathrm{~cm}(2.6 \pm 1.3$ $\mathrm{cm}$ )。浸润㾌の病理組織型では、2a3 15例、2a1 4例で、 $2 \mathrm{a} 2$ は見られない。肥満度、ケトレー指数 28 以上 (肥満) 0例、26-27 (やや肥満) 3例、20-25 (普通) 18例この うち 22 以下 12 例、19以下（やせ）10例になる。

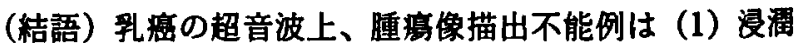
癌では、 $1.0 \mathrm{~cm}$ 以下に、また腫注徍が大きくても硬癌の 場合がおり得る。（2）管外漫潤の少ない癌では生じ易い。 (3) 拜房の小さい場合、描出率が悪い。 
场医科大学第一外科

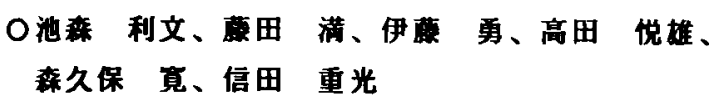

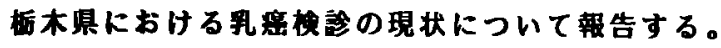

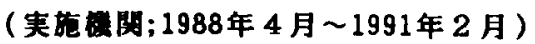

湌診は同診表に記入渚、当教室の医師による視出診 を行い、所見のある者に対して同時に両略乳替を技師 が超音波模查（アロカSSD-125，7.5HHzメカニカルセク タ)を行いVTRに記绿した。判定は当数室の超音波 専问医が行った。

1988年度か51990年度と受診者数は 40 隿、50 代が中で增加㑯向にある。(10,162人、14,082人 17,484人）また、㛟診時要超音波㛟査とされた者は 平肉8.0\%であった。

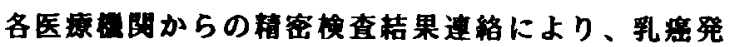
見事は各年度でそれぞれ0.11\%(11人)、0.09\%(13人)、 0.05\%(9人)であった。なお、1990年度については1991 年 2 月末現在で集計䊅果である。

菒㛟での超音波榙查実施率を上げるにはV T Rを用 いた鼓影方法では限界があり、光ディクとマイクロ コンビュータを用いた読影システムを開発した。この システムについても霞する。

296 超音波画像による我痓の脄窝リンバ慨

転移診断一200侀の検討

防得医大第一外科

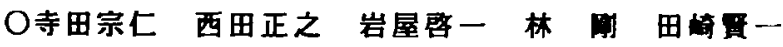
山崎 健今井順田巻国義平出星夫玉熊正说

1987年9月から1991年4月の間に当科で手術を施行し

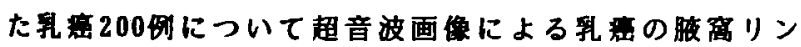

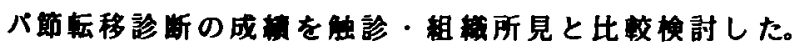
【万法】掼器はアロカSSD270・水浸アークスキャンを 便用した。超音波所見はIから VにClass分類し、III以 上を転移隄性とした。組樴学的にはリンバ節の最大割

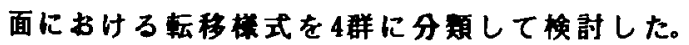

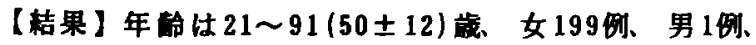
STAGE I 66例、II 93㑬、III33例、IV 8例。組械学的には

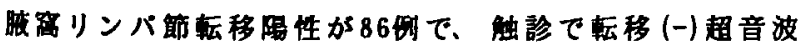

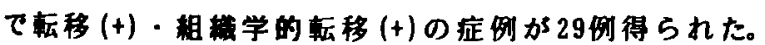
諎法は sensitivity 0.51 、specificity 0.89 、accuracy 0.72 、超音波ではsensitivity 0.85 、specificity 0.65. accuracy 0.73であった。

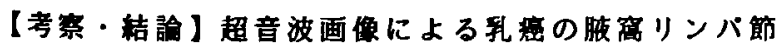

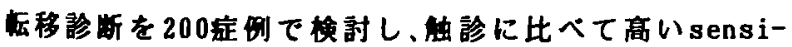
tivityが得られた。本法は無侵簡便であり、より見 落としの少ない㛟㚗法として有用と考えている。
検討

鳥取大学第 2 外科

○林 英一、中村廣繁、原 宏、森透

当科において過去 16 年間に経験した原発性乳病症 例は 206 例であり、その5ち tnm病期分類で stageIに 分類された症例は 109 例 (52.9\%)てあつた。その 5 年

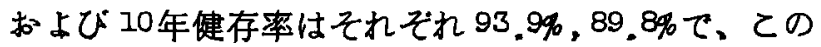
間 7例の再発例を認めている。この再発ををたした 例の背景因子につを検討した。

その結果、t功 $\alpha$ 群は t Ino群に比し有意に高率に再 発をきたし、t2no群はその中間の再発率てあつた。は た術前生検施行群と非施行群との間にも有意な再発率 の差を認めた。更に、硬癌症例は、特に溇頭腺管癌症 例に比し再発ををたし易い傾向にあつた。

stage I症例において、n+群、生検施行群、腫瘍 径 $2 \mathrm{~cm}$ 以上、硬癌症例を予後不良群とすれば、これらは 釈癌全体の予後不良因子に相当するすのであり、てれ らの因子を持つstageI乳癌に対しては、術後補助療 法あるいは followーupに関し、日tageIIあるいはそれ 以上の乳癌に対するのと同等の対応の仕方が重要と考 える。

298

非浸潤性乳癌の臨床病理学的検討

癌研究会附属病院外科, 同 病理 ${ }^{*}$

○渡辺 進, 岩瀬拓士, 吉本賢隆, 霞 富士雄,

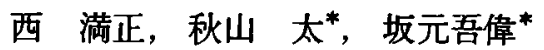

1975 年より1989年までの15年間に癌研外科に於 て, 252 例の非浸潤性乳癌の手術を施行した。今回, 非浸潤性乳癌の臨床と病理組織を含的検討した。

症例の組織型は，非浸潤性乳管㿋 248 例 (98.4\%), 非浸潤性小葉癌 4 例 (1.6\%)であった。同時両側乳癌 10 例, 異時両側乳癌 15 例が含まれていた。

非浸潤性乳癌 252 例のうち, 腫瘤の触れないT0 乳 癌は 50 例 (20\%)，マンモグラフィーにて石灰化を認 めたもの81例 ( $32 \%)$, 乳頭分泌は 43 例 $(17 \%) に$ みとめた。

さらに, 非浸潤性乳癌のうち生検を行ったものは 187例（74\%）であった。非浸潤性乳癌の診断には適 確な部位の同定による生検と, 病理全割による組織診 断が有用であった。 
繁友総合病院外科

O嶋田昌彦, 石井忠弘, 石川広記, 吉田博之, 渡辺 衛

1988年 1 月から 1991 年 3 月までに当科で根治手術を 受けた原発性乳癌は114例であり，12例( $10.5 \%)$ の非 浸潤性乳管癌を経験した。全例女性であり，年龄は 34 葴から71歳までで，平均は50歳であった。隀瘤あるい は硬結を主訴として来院したものが 7 例て，乳頭異常 分泌が2例，乳頭の変形が 1 例，検診の 2 次精查が 2 例 でった。腫瘤あるいは硬結として触知可能なものは10 例( $83 \%$ ) であり，4例 (33\%) に乳頭分泌を認めた。 mammmogr aphyて腫瘤陰影を認めたものは 5 例( 42\%)で, 微細石灰化像は 4 例 (33\%) て, 合わせて 8例(67\%) に異 常陰影が出現した。超音波検査で乳癌の疑診と診断され たものは2例(17\%)に過ぎなかった。分泌物の細胞診は3 例に行わ㧈，ClassIが1例ＩIが2例であうた。睡瘤の穿 刺吸引細胞診は5例に行われ，ClassIIIが2例, Nが1例, Vが2例であつた。確定診断を得るために1例にmicroー dochec tomyを行い，9例に切除生検を行った。10例は術 前に非浸潤癌の診断がついたため, 乳房温存手術が 1 例, 胸筋温存手術が10例に施行され，拡大乳切は 1 例 のみであった。全例に腋窝郭清を行ったが，1例もり ンパ節転移は認められなかった。

德盘大学第 2 外科。同 - 医绩短期大学部

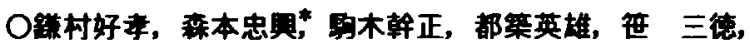

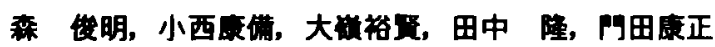

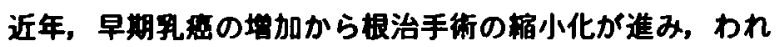

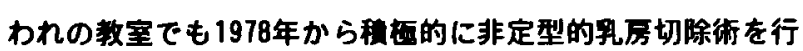

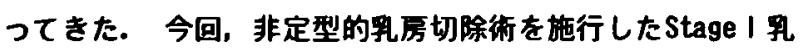

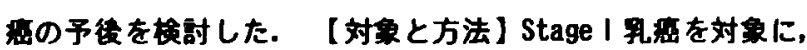
1978〜87年にPatey法を施行した94体（以下PA群），Auchincloss法を施行した11例（以下AU群）の予後を、1971年〜77年 に定型的乳房切除術を施行した28倒（以下ST群）と対比した。

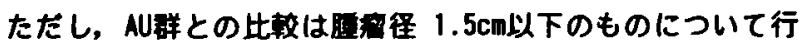
つた. 生存率の出は Kaplan-Meier 法により行い，模定は Logrank法によつた.【楉果】(1)平均部洋リン八節個数は AU 群15.6個，PA群18.5個，ST群14.3個であった. (2)PA群：ST群 の対比では予啳に差はなく，5年㯬存率 92.0\%: 89.3\%,5 年生存率 96.4\%: 92.9\%であった. (2)AU群：PA群：ST群の 对比でも予後に差はなく，5年艇存率 100\%: 95.4\%: 92.9 \%，5年生存事 100\%：97.8\%：92.9\%であった.

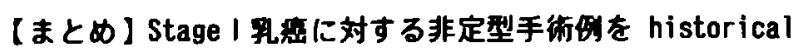
に定型的手術例と比䖝した結果，予後に差はみられなかった。
301

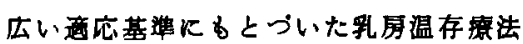
250 例の経榆 茅っ崎徳洲会総合病院(1)、度大学医学部故射線科(2) 竹大 襀一(1)、雨宫 厚(2)、近藤 破(2)

（目的）我かが行ってきた、極めて広い通応基策飞基

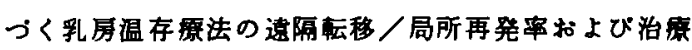
Кとるな5合併症に湌㣙を加える。

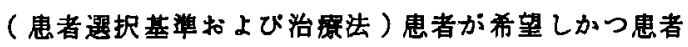
が满足する形で乳局を温存出来るよらであればすべて

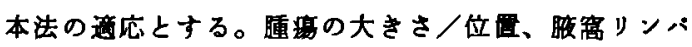

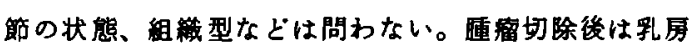

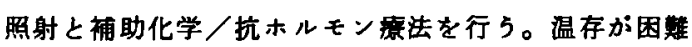

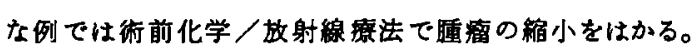
（成榞）温存原法を希望した265名中、250 乳局 の温存か可能であった。平妁視察期間恃 28 月月。遠

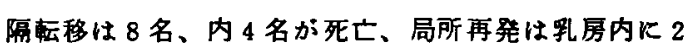

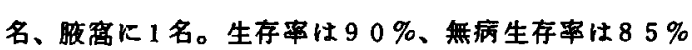

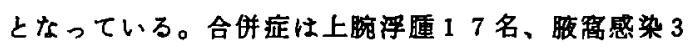
名、故射炎皮消炎 7 名、帽炎 5 名であった。 （結論）1，釈房温存を希望する患者のはとんどに本 法が可能であった。2，遠槅転移率/局所制御率は釈

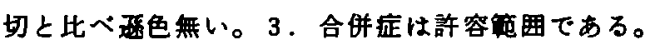

302 胸骨傍リンパ節の転移様式からみた内 側乳癌に対する乳房温存手術の適応 京都第 2 赤十字病院 外科 竹中 溫, 藤井宏二, 佐久山陽, 泉 浩, 高橋 滋, 加藤 誠, 井川 理, 新畑 辜, 松繁 洋, 徳田一

【対象および方法】胸骨傍リンパ節 (PS) 郭清を施行し た内側乳癌 187 例を対象として，T, Nおよび腋简転移 度 $(n)$ 別のPS転移の有無加ら，いかなる内㑡乳癌加乳 房温存手術の適応となるかを検討した。

【結果】(1)T因子： $1.5 \mathrm{~cm}$ 以下の症例ではPS転移例は なかった。(2)TN Stage：I・II・IIIそれぞれ11.1\%・ $13.6 \% \cdot 29.2 \%$ であった。(3) n因子： $\mathrm{n} 0 \cdot \mathrm{n} 1 a \cdot \mathrm{n} 1 \beta \cdot$ n2 それぞれ 5.8\%・25.6\%・26.7\%・47.8\%であり， $\mathrm{n}(+)$ となると高率のPS転移を認めた。(4)Tn Stage： I・II・II それぞれ 5.5\%・17.8\%・41.7\%であった。 (5)腋窝転移部位：1c (29.4\%)，2 または $2 \mathrm{~h}(41.7 \%)$ に転移を有する症例では高率のPS転移が認められた。 しかし，1c，2，2hに転移を有する症例は, 腫瘤径の 大きいものが多く認められた。

【結語】乳房温存手術の適応となる症例は， $1.5 \mathrm{~cm}$ 以 下の腫瘤でTN Stage, Tn stage とむに1の症例と考え られる。また，術中 1c，2，2h亿転移陽性の場合は，術式 を変更しPSの郭清を施行するととが妥当と考えられた。 
德島大学第 2 外科で行われた䍃貧温存療法について 模討した。1989年以前に高崳、合併症、手㫦拒否など の理由から10例に行われていた。病期は、1期6 例、 II 期 4 列であるが、視察期間が中央犆 5 年 1 力月で他 病死 1 例を除き、すべて生存していた。1989年以降は

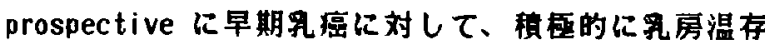

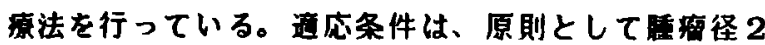

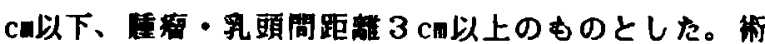
式はquadrantectomyまたはlumpectomyとレベル IIまで

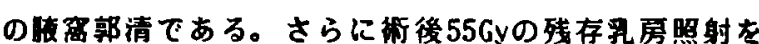
行った。n(t)例にはTAM. 5’-DFURによる蒲助療法を

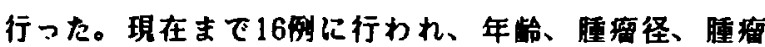
- 采頭問距离は、各々平均值で 48.4 歳、 $1.1 \mathrm{~cm}, 3.8 \mathrm{~cm}$ であった。非浸洞性胃管痊 4 例、角頭腺管癌 3 例、充 実性管癌 2 例、硬度 6 例で、リンパ節転移は 5 例(35. 7\%)にみられた。修後の多数切片標本による検索で乎 管内集展による癌遗残が例(18.8\%)にみられた。い ずれも修式の変更は行わなかった。段察期間はまた中 央值 6 力月であり、今後のfollow up が必要である。

島根医科大学第二外科

○久保田博文, 小野隆司, 深㳯公朗, 松尾進, 中村蹱久

昭和62年以降の乳癌46例中16例に対して, 患者の希 望を参考にして乳房温存手術を施行した。適応は，原 則的にはStage I のみとし，腫瘍占居部位や乳頭から の距離は問わないこととした。手術は, surgical marginが少なくとも $1 \mathrm{~cm}$ になるうにし, 病巣直下の 大胸筋筋膜は切除, 腑窝リンバ節郭清はNo.1のみとし た。術後 2 ないし 3 週間後から全乳房照射を $50 \mathrm{~Gy}$ 行っ た。今回の検討対象は34歳から78歳までの女性で, 占 居部位は C が11例，Aが2例，Dが2例，Bが1例で ある。病理組織学的所見で, 著明な comedo形成は2 例，多発性病変をみたのは 1 例であったが, surgical marginはすべてfreeであった。術後合併症では，放射 線性皮虔炎 4 例，上肢リンバ浮腫 1 例が認められた。 全例局所再発なく, 最長 3 年 9 力月の現在健在であ る。
305 急性膵炎晚期合併症としての膵膿瘍の

治療方針决定に果たす画像診断の臨床的意義 帝京大学医学部第一外科

○安田秀喜, 高田忠敬, 内山勝弘, 長谷川 浩, 土屋繁之, 三須雄二, 岩垣立志, 四方厚一

【はじめに】急性膵炎の晚期合併症のひとつである膵 膿痬の治療方針决定に果たす画像診断の臨床的意義を 検討した。【対象と方法】帝京大学第一外科で経験し た急性膵炎症例は 102 例であり，厚生省による重症度 判定基準では重㱏25例，中等症30例,軽症47例であった。 102 例のうち膵膿瘍を形成した症例は 9 例でおった。乙 れら9例の画像診断所見と治療成績を検討した。成績】 (1)入院時造影CT所見；9例全例に，膵腫大を認め，さ らに膵内部に造影CT值か20前後の低吸収域を認めた。 (2)経過 ; 全例において，入院時に認めた膵内部の低吸 収域か，臨床症状が改善されてむ低吸収域として残っ た。(3)治療 ; 造影CT所見にて膵膿瘍の輪郭が明瞭にな った時点で，8例に開腹による膵膿瘍ドレナージを施行 し，1例に超音波ガイドにより経皮的に翤瘍を穿刺吸引 した。【まとめ】造影CTによる画像診断は, 造影 CT 値を測定することにより膵膿瘍の発应を予測でき，さら に膿㾴の輪郭が明瞭になった時点で手術おるいは経皮 的ドレナージの必要性を指摘でき臨床的意義を認めた。

\section{6 急性壊死性膵炎の晚期膿湯に対する治療} 東京女子医科大学消化器外科

鈴木 衛、羽生富士夫、今泉俊秀、中迫利明、松山英樹、 原田信比古、羽鳥 隆

重症急性膵炎の発症早期の患者に対しては開腹手術を適 応することなしに、徹底した全身集中管理で良好な成績 が得られるを埌告してきた。今回は、急性膵炎の晩期合 併症である膿瘍に対する治療について報告する。1984年 以降に全身集中管理による治療を必要とした急性膵炎30 例のうち12例に膿瘍の合併がCTによって確認された。こ

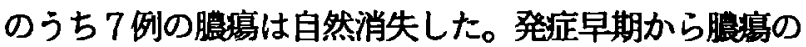
感染をみた 2 例ではCTドレナージで、膿汁の排出ととも 膿揘は消失した。 3 カ月以上も膿瘍が消失しなかった 3 例では、疼痛と王迫症状のため治療が必要であった。CT 下ドレナージを行ったが、晨瘍の内容物は除去されず、 逆行性感染による悪寒発熱をみた。開腹手術で腹湶を解 放すると、感染した膵壊死物質が多量にみられた。デブ リードメントを行い250gから800gの壊死物質を除去し、 膿䲴腔に洗浄千ューブを留置し術後生理食塩水で持続洗 浄した。術後のCTで嫧瘍の消失が確想できた。急性膵炎 の晚期合併症の膿瘍に対してはCT下ドレナージも有効で あるが、膵壊死物質が充満する膿痬にはCT下ドレナージ は無効で、開腹操作による完全な除去が必要である。 

式の孯念として膵醭素が胃内で失活し消化吸収障害が 起こりはしないかというととがある。そこで，PPPD-PG 後の膵睹素活性を小腸・䔬便について検討を行なった。 【結果】アミラーゼ・リパーゼ活性は， $\mathrm{pH}$ 依存性があ り， $\mathrm{pH} 3.0$ 以下の時には，活性は見られず，不可逆 性であったが， $\mathrm{pH}$ の上年と共に活性が高くなった。 それに対し，トリブシン，キモトリプシン様活性は， 強酸時にも失活せず，保たれ， $\mathrm{pH}$ の上昇に伴い可逆 的に活性を取り戻した。小腸液中の膵醭素活性は，ミ ルク負荷啳では負荷前に比へ，強く活性が認められ， かつ負荷後では、アミラーゼアイソザイムにおいてP型 優位であった。蕒便中の総了ミラーゼ佸性は $383.0 \pm$ $41.1 \mathrm{IU} / \mathrm{g}$ で, P：S㤌 $62.6 \pm 3.9: 37.4 \pm 3.9$ であ つた。リバーゼ活性は561.1土65.3であった。トリプ シン,キモトリブシン様活性は全例に認められた。

【総論】PPPD-PG術㣪の膵醳素活性は, 小腸液内 ならびに蕒便中にも十分認められ，乙の術式を支持す るものであった。

\section{8 膵外傷に対する治療法の検討}

市立伊勢総合病院外科 ○山本敏雄, 世古口務, 中浜貴行, 勝峰康夫, 稲守重治

【対象及び方法】最近 10 年間に経験した脺外傷の 10 例 について,その診断や治療法の選択について検討した。 【結果】膵外傷の原因はハンドル或いはシートベルト外傷7 例，その他 3例。年齢は7才〜69才(平均35.8才), 性差は なかった。入院時,全例強度の腹痛があり，4例は呕吐を 伴った。ショック例は腹脘内大量出血合併の1例であった。 血清アミラーゼ值は全例上昇し, 1000 IU以上は経過中, 仮 性辌胞の発症が多かった。初診時CT施行の6例は全例膵腫 大や膵周囲液眝留が確認された。治療は他院で緊急開腹 ドレナージが行われた2例は,術後膵液瘦及び幽門狭害を 来し再手術(膵体尾部切除,幽門側胃切除兼Partington 手術)を行った。他の8例中6例は保存的治療を行い,3例 は経過中仮性亳胞か子発生した。自然消失は 1 例で，他の 2例は亯胞・胃吻合術或いは衰胞切除を行った。緊急手 術は膵鈎部広範挫傷及び完全脺断裂の各1例で各々 pancreaticoduodenectomy [PD],脺管断裂部端々吻合術を 行った。予後は緊急PDを行った1例が術後MOFで死亡し た以外は全例良好な結果を得た。【結語】脺外傷の診 断にはアミラーゼ值,経時的CTが有用で,病態に応じた治 療法，術式を選択するととが重要であると思われた。
309

福岛県立医科大学 第二外科

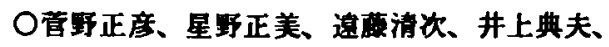

小山善久、鬼满圭一、阿部力哉

教室におけろ样性低血精症例は6例て、うち5例はイ ンスリノーマ、1例はランダルハンス氏島通形成（ラ氏 島通形成）であるか、今回これら6症利につき特に局在 診断の面から模討し報告する。これら6症例は低血䈐下 におけるインスリンの通制分洛の指楆であるPBS/IRIを 测定することによりその存在診断は容易であったか、 その術前局在診断はCTで6利中1利に锠診、腹路動眽造 影ては6例中1利に能診にととまり、経皮経肝門脈血革 ンブリンク(PTPC)で3例中2似、胃十二指渴造影(GDA)て 2例中1例、digital subtraction angiography(DSA) $C$ 1例中1例に確定診断が得られた。特にPTPCは明らかな 畽湯像として描出しがたいラ氏島通形成て有用であっ たが、インスリーマの2列中1列ではstep upを瑟めず、 GDAにて局在診断をなし得た。DSAld隀的陰影の描出に 優れ、インスリノーマの局在診断には今盽最も有用に なると思われる。以上のことく各診断法には一長一短 があり、これらを粗み合せ、さらに術中USを併用する ことによりほほ琟実な局在診断ができると思われる。

310 膵全摘術後の血糖管理（人工膵島使用

例と非使用例の検討 )

東京医科大学外科

○吉松昭彦, 木村幸三郎, 小柳泰久, 青木達哉, 土田明彦, 青木利明, 小澤 光, 小澤 隆, 安田大吉, 粕谷和彦, 宇田 治, 浅見健太郎

最近 5 年間に, 教室では 12 例の膵全摘術を経験し, うち 4 例にべッドサイド型人工膵島（Biostator）を 使用した。術後経静脈栄養期の血糖管理について, 人 工膵島使用例之非使用例に分け比較検討したので報告 する。

人工膵島使用 4 例は，それぞれ第 $1-2 ， 5-6$ 病日， 第 5-7病日，第 $2-3$ 病日，第 10 病日に人工膵島を使用 した。人工膵島非島使用例は， 1 時間每に血桾を測定し， インスリンあるいはグルコースの補充を行ない。血糖值 $150-250 \mathrm{mg} / \mathrm{d} \ell$ を目標とした。インスリン投与量, グルコー ス投与量は人工膵島使用, 非使用例とも経過とともに 漸增した。グルコース・インスリン比は全経過を通し て使用例の方が低く，十分なインスリンが投与されて いると考えられた。非使用例での血糖コントロール不 良例に対して，人工膵島の使用はすみやかに血糖値の 安定が得られ，グルコース・インスリン比の指標がで きたため，以後の血糖コントロールに有用であった。 
311

FAP (Fetoacinar Pancreatic Protein)

の臨床的有用性-CA 19.9，CEAとの比較倹討

東大医科研外科，蓮見酒研兔度* I.R.S.C.France**

O藤井祐三，清水浩，江里口正純，関口守正，蓮見賢一郎， M J .Escribano**

FAPは，ヒト胎児膵の抽出物を免疫原として作製された モノクローナル抗体丁-28により認識される膵に対する䁍器 特異性が高くoncofetalな性質をむつ分子量 $110 \mathrm{~K} . \mathrm{Da}$. の 糖蛋白である。今回，精製FAPを免疫原として新たにFAP と反応するモノクローナル抗体M128-Fを作製した。 M128-F 抗体は，免疫組織学的にJ-28抗体と同様の反応 性を有し膵癌に隣接する腺房細胞之強く反応したが他の葴 器とは反応が見られなかった。患者血清 429症例のFAPを J-28，M128-F の両抗体を用いたSandwich EIA により 湘定し，同時にCA 19.9,CEAを測定し比較恰討した。FAP のcut -off 值は正常血清より $11 \mathrm{U} / \mathrm{ml}$ とした。膵癌 36 例中 24例か湯性を示したが脺以外の疾患での陽性率は低值であ った。荟湢に対するsensitivityは，FAP: 66.7\%,CA19.9 : 72.2\%, CEA : 47.2\%であり, specificityは, FAP:86.1 \%, CA 19.9 : 75.8\%, CEA:84.9\%を示した。FAPは,CA 19.9，CEA とは相関関係が認められず，CA 19.9 との combination assayでは陽性率92\%(33/36) と上昇し臨 床的有用性が示唆された。

312 再発膵癌例における血清 CA19-9 の検討 大阪大学第 1 外科

○道清 勉、宮田正彦、上池 涉、田中康博、

伊豆蔵正明、伊藤寿記、角村純一、中室 誠、

弓場健義、山口時雄、姆中信良、今分茂、

林 克英、江本 節、水谷 伸、松田喗

[目的]膵切除術後再発例において CA19-9 の推移と 予後との関保について検討した。［対象と方法］切除衍後 再発脺管癌13例を対象とした。男7例、女6例 (51-70歳)。 徒後、CA19-9 か正常化 (37U/ml 以下) した例を正常化 群 $(\mathrm{n}=6)$ 、正常域にまで下降しなかった例を非正常化群 （n=7）とした。予後の検討には、果積生存率 (KaplanMeier 法）を用いた。［成績] (1) 正常化群と非正常化群 の術前の CA19-9 には有意差を認めなかった。正常化 群と非正常化群の間には、術後の CA19-9 倍加時間广 らびに術後の累積生存率に有意差を喼めなかった。(2) 術 後の CA19-9 が術前值を越えるまでの期間と、術後の 生存期間との間には有意の正の相関を認めた。(3) 衍後の CA19-9 倍加時間と衍後の生存期間との間には有意の正 の相関を認めた。［まとめ］脺癌切除例においては、術 後の生命予後の予測に、哜後の CA19-9 の正常化の有 無は有用ではなく、術後の CA19-9 が術前値を越える までの期間あるいは CA19-9 倍加時間が有用である。
胃癌手術における脾合併切除の意義 大阪警察病院外科 一㭪後合垪症からみた臨床的検討一

○荻野信夫, 中尾量保, 藤田修弘, 前田克昭,

濱路政靖, 仲原正明, 岸本康朗, 中 好文,

宮崎 知, 長谷川順一, 米田光宏, 川平洋一,

数尾 展, 前田 晃, 中村順一

脾椇傷に対する処置として感染防御の面から脾温存 の必要性が指摘されている。一方胃癌に対するリンパ 節部清時の脾摘に関する腫焬免疫学的な検讨は多いが， 術後感染の検討は少ない。そこで胃演全摘例における 脾合併切除の術後合併症について検討した。過去 5 年 間の胃癌の胃全摘症列 89 例を A群：胃全摘のみ 40 例, B 群：胃全摘十脾摘群 49 例（腈朝合垪切除 28 例を含む）に 分け, 術後合併症 (腹腔内感染： 17 , 膵炎：3, 創感染 $: 5$, 虂胸: 1 , 肺炎: 3 , 敗血症: 4 ) の発生頻度を比較した。 【結果】合垪症全体の頻度は B 群 ( $45 \%)$ がA 群 (34\%)に 比して高かった。肺炎，敗血症の頻度は差はなかった が腹腔内感染, 創感染, 膿胸, 勝炎等の感染症の頻度 は B 群の方が $\mathrm{A}$ 群より高かった。また合併症による死 亡は A 群 2 例 ( $5 \%$ )，B 群 7 例 (14\%)であった。

【結語】胃癌全摘後の合併症, 直死例は聘摘群に多く， 脾摘後の合併症に注意を要すると考えられた。

314 おける門脈大循環系シャントの検討

東京女子医大消化器病センター外科

O大坪媇人. 高崎 健. 济陽高䅹. 次田 正. 山本雅一. 有賀 淳. 宮崎正二郎. 鈴木隆文. 中上哲雄. 太田正穂 小林誠一郎。羽生富士夫

【目的】肝疾患ではアンモニアの肝での処理能の低下 や、門脈大循環系シャントのため血中アンモニアが高値 となる。そこでフンモニアを指標として門脈大循環系シ ヤントの検討を行った。【对象と方法】食道静脈痛 5 例、肝細胞瘤 5 例、肝外門脈閉塞症 1 例である。大腿静 脈よりカテーテルを挿入し上大静脈、奇静脈、右房、肝 静脈、腎静脈、腸骨静脈より探血する。

【成績および考察】1!例中10例で右房に比較し左腎静脈 血でアンモニア值が高値を示し、1 例に右腸骨静脈血で 高値であった。奇静脈血では高値を示さなかった。肝静 脈血では 7 例で右房に比較して低值であった。門脈圧六 進症では画像診断での描出の有無にかかわらず脾腎静脈 シャントが存在し、奇静脈を介する侧副路の们流昂は比 較的少ないと思われる。またシャント閉鎖後肝機能の回 復する症例は肝静脈血アンモニアの低い症例つまり肝内 シャントがすくなく、肝でのアンモニア処理能の良好な 場合であると考えられる。 
315 純エタノールを用いた食道静脈瘤硬化 療法：エタノーラミンオレートとの比較研究 福岡市民病院外科

○小柳信洋, 岩永哲也, 田村重暗, 矢野和浩, 竹中賢治, 池田俊彦

【目的】内視鏡的硬化療法 (EIS) 硬化削としての純工 タノール（ET）の有用性愉討のため、Prospective studyによりエタノーラミンオレート（EO）と比較し た。【方法】 Risky varices 有する肝硬変症各10例 がET群及びEO群に振り分けられた。肝癌合併はそ れぞれ 2 及び 3 例てあった。両群間に統計学的差異は 認めなかった。EIS手技は九大 2 外科法に準じた。 すなわち、下部食道に全周性潰瘍形成をむって静脈瘤 の eradication とするあのである。結果】平均追跡 期間 6.4 力月の現在、ET群江脳出血、肝癌で各1例、 EO 群恃肝癌にて 2 例か洌亡した。 eradicationまて に要した硬化削総量、注入回数平均は ET 群 $16.8 \mathrm{ml}$ 、 3.7 回、EO 群 $48.6 \mathrm{ml} 、 4.6$ 回と ET 群が有意に少な かった。初回治療後の総ビリルビン值上昇、血小板数 减少は ET 群が有意に軽度であり、また $\mathrm{E}$ 群 6 例に ヘモグロビン尿が見られたのに対し、ET群では皆無 であった。

【結語】純エタノールは肝障害高度例や腎機能障害例 におけるEISで有用と考えられた。

316 食道周撸息急出血例に对する内视

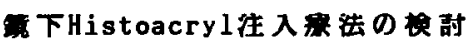

果京女子医科大学付属第二病完外科

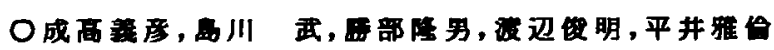

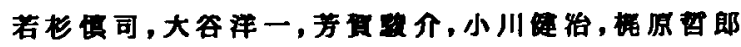

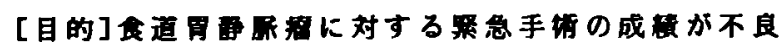

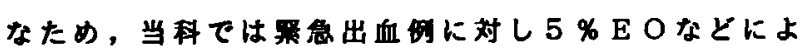

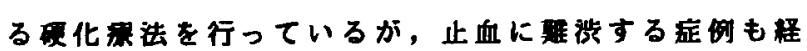
的した。今回，このような症例に对してHistoacrylに よる往入然法を行い，良好な粘果を得たので報告する。

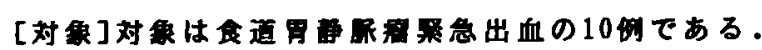

内䂵は男性 6 解, 女性 4 例, 出血部位は食通 3 例, 胃

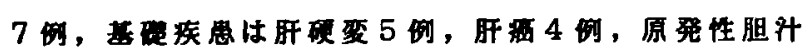

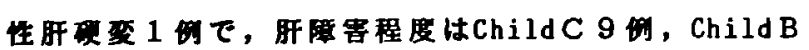
1 であ。内視籍直視下にて出血部位の近增を穿刺 し, Histoacryl 0.8-1.0mlを解踏内に注入した。 [成耤]全例に止血が可能であった。予後をみると， 1 年10力月程逗例をはじ，覞在 5 例が生存中である。 再出血は1例に䞏めたが，再注入にて止血しえた。死

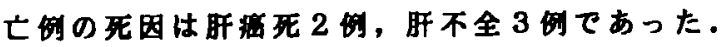

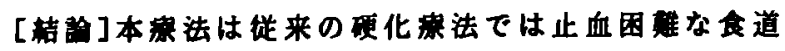

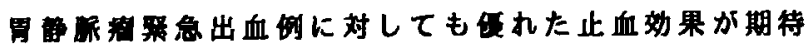

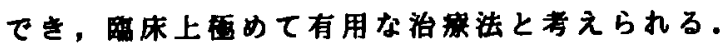

317 急性虫垂炎の最近の動向

一虫垂切除症例の臨床・病理学的検討上り一 日本医科大学第二外科，目白第三病院*

○長浜充二 坂上信也*, 中江純夫*, 生司佑

虫垂炎は今日でる外科領域，特に一般病院におんて は日常頻繁に遭遇する疾患の一つに変りはない。更に 抗生物質の開発や麻酔, 手術方法の確立などから現在 では虫垂切除術は最す安全な手術の一つであるとの認 識が広く漫透している。しかし，施行された虫垂切除 術についてその妥当性を検討した報告は少ない。今回 我々は一線病院における最近 5 年間の虫垂切除症例 119 例を対象とし, 手術所見及び病理所見との対比か ら妥当であった手術と妥当性を欠いた手術を検討した。 更にこれを基盤として(1)年龄，性別などの背景，(2)初 発症状，食欲不振や湢気・湢吐の有無なとの自覚症状， (3)発熱，王痛，腹膜刺激症状，筋性防禦などの臨床症 状，(4)白血球增多，尿所見などの検査所見，(5)発症か ら手術までの期間, 術後の排カスゃ食事開始までの期 間とその関係, 術後合併症の頻度とその内容, 抗生物 質の使用状況，入院期間などの臨床経過，6皮庫切開 法, 腹水の有無，虫垂切除法，ドレナーシ்の有無，䔬 石の有無などの手術所見を分析し，妥当な手術を行ら ための診断のより所や手術の功罪につき検討するとと るに最近の急性虫垂炎の動向につき報告する。

318 性について

急性虫垂炎に対するエコー診断の有用

東京医科歯科大学第 2 外科，榛原総合病院“

○小鳮一幸，河原寛人，能 炳椿，村上三郎，

安田 滋, 田中善樹”, 中村孝哉”, 三島好婎

急性虫垂炎のエコー診断は今日では一般的な補助診 断となっている。

今回は術前のエコ一所見之、理学的所見、白血球数、 C R P , 病理所見との関連を比較検討したので報告す る。

【対象】1990 年 1 月から 1991 年 3 月まで急 性虫垂资の診断にて手術を施行した 93 例。

【方法】これらの症例につき、術前の白血球数、C R $P$ 、理学所見、病理学所見につを比較検討した。エコ 一所見は虫垂の措出の有無、短軸往、高エコー帯の有 無、膿瘍形成、エコーフリースベースの有無の検討を 加えた。

【結論】(術前のエコーにより、急性虫垂炎の程度の 判定が可能である。(2)エコーをルーチンに行うことに より不要を手術を避けるととがでさる。(3)虫垂资の進 行度の判定に置いて、特に、高エコー帯の有無が有用 である。(4) C P ，筋性防御、ェコ一診断を組み合わ せるととにより、診断能は向上する。 
意義

富山市民病院小児外科

○宫本正俊，南部 澄

過去 2年間に, 初診時に定量化CRP (C-Reactive Protein) 検査を施行した83例の小児急性虫垂资症例飞 対して, CRP 值と虫垂资各病期との関連性加ら本検査 法の診断的意義について検討したので報告する。

結果：初診時 CRP の平均値は, カタ几性 $3.2 \pm 2.4 \mathrm{~m} /$ $\mathrm{d} 1$, 蜂巢織炎性 $7.4 \pm 1.6 \mathrm{mg} / \mathrm{dl}$, 穿孔性腹膜资合併例で

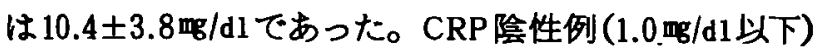
はカタル性で27例中10例 (36.796)，蜂窂織资性は33例 中14例 (42.0\%) なのに対し，壊疽性，穿孔性虫垂炎症 例でのCRP陰性例はなく，両者間にはっきりした有意 差か認められた。CRP値と白血球数では，事前に抗生 用を投与されていた症例では両者は相関していなかっ た。またCRP值と血沈値との関連では, カタル性, 蜂 粱较炎性では一定の傾向はなかった。

考察：定量化 CRP 検査は, 白血球数や血沈值之較へ て, 虫垂炎の各病期に比較的よく相関しており, 特に 壊瘨性や穿孔症例飞ついては，全症例が高値を示す。 このことから，診断に苦庶するような腹痛患児の手術 の適否及び時期の決定に極めて有用と扣もわれる。

320 当院における最近 2 年間の急性虫垂炎

についての検討

済生会濯賀県病院外科

○今西 努、湊 博史、米山千最、西植 隆、

石井䒹、渡召信介

平成元年 1 月から平成 2 年 12 月までの最近 2 年間に 当院にて経匼した急性虫垂炎及びそれが疑われ入院経 過観察を要した症例は 298 例であった。今回我々はこ れらの症例につき、年觝、切除虫垂の肉眼的病型、術 前の抗生骫投与の有無などに着目し検討、文献的考察 を加えた。

上記应例の年齢分布は 3 歳から 81 歳までで、平均 27 歳であり、男 170 例、女 128 例であった。この中で虫 垂炎之診断し開腹術を施行したのは 238 例であった。切 除虫垂の肉眼的病型分類ではカタル性 48 例 $20 \%$ 、蜂 简織炎性 115 例 $48 \%$ 、墒㾝性 51 例 $21 \%$ 、そして虫垂 に異常を認めなかった症例は 24 例 $10 \%$ であった。

崄断後、術前までの間に抗生剂を投与した群之非投 与群で㓣がし開・化渡したのは投与群では 19 例中 3 例 $16 \%$ 、非投与群では 30 例中 3 例 $10 \%$ 、菜郕の投 与よりも術中の操作など他の要因が重要であるように 考えられた。
の考え方に関するアンケート調査

和歌山県立医科大学消化器外科

○佐々木政一，谷村 弘。湯川裕史, 川口富司。

坂本幸具, 柏木秀夫. 内山和久

強力な経口抗菌薬の開発や超音波検査をはじめとす る画像診断の進歩により，急性虫垂炎に対しても保存 的療法を選択する外科医加增加している。今回，我々 は急性虫垂炎に対する外科医の治療方針について，和 歌山県および周辺地域の外科医243名にアンケートに よる意識調查を行った。その結果. 回収率は69.1\%て あった。「直ちに手術を施行する」あのは19.6\%にす きず、「症状の軽度のものはひとまず保存的療法を試 みる」あのが80.49にあ達しているてとが判明した。 3 年間の急性虫垂炎 6,610 例のうち，手術をせずに保 存的療法のみで軽快治癒したものは 1,680 例 (25.496) あった。その際，使用する抗菌薬は「経口薬のみ」か 22.5\%．「注射薬のみ」が $34.9 \%$ 。「経口薬と注射薬 の併用」が42.6\%であり，種類ではセフェム系薬郕が あっと屯使用されていた。さらに，保存的療法選択の 診断基準についても言及する。

322 排便機能障害のmanometric study $\nwarrow$

上る解析之治療法の選択 藤田保健衛生大学消化器外科

○黒水丈次, 宮島伸宜, 内海俊明, 遠山邦宏, 佐藤美信, 滝沢健次郎, 奥村嘉浩, 丸田守人

目的：排便機能障害例をmanometric studyKより解 析し, 臨床症状と検討するととにより, 合理的な治療 法選択の一助とする。

対象お上び方法: 直腸癌で超低位前方切除( 吻合部 $<\mathrm{AV4cm)}$ 施行例 6 例, 分婏時の会陰部裂賃に上る肛 門機能不全 3 例，庤瘦の術後肛門機能不全 2 例を対象 とし, 直腸肛門に病変のない10例を対照とした。検案 はmanometric studyに上り生理的肛門管長HPZ, 肛門 管最大静止圧MRP, 近門管律動波RW, 最大随意収縮 EMVP, 直腸肛門反射RARの有無, 便意発現最少量 FSお上び最大耐容量MVPを測定した。臨床症状は問 診に上り排便回数 BM，便とガスの識別能およびsoiling の有無などを聴取した。

結果：超低位前方切除後の排便障害は経時的に改善 したが, 適応の決定には術前の肛門機能の検討が必要 である。分娩や肛門の手術に上る排便障害は外䢸門括 約筋の障害が主であり(時に内䢸門括約筋も), 解剖学 的に正確な手術により良好な改善が得られた。 
腸㱏例の桧討

広島大学第一外科、同総合診療部 ${ }^{*}$

O竹末芳生、横山隆、览玉節、平田钽明、松浦雄一郎

「目的」成人の排便障害を伴 5区大結腸例を大别し検 討した。「方法」正門内压娭查 (Inf used open tip 法) を行い、直腸肛門反射、静止圧 (ARP)、随意収縮圧 (ASP)を測定した。「成績」直腸且門反射異常を呈す る疾患として、久如した anal achalasia 4 例、非典 型的反射を示したمutlet obstruction 2 例を認めた。 ARP高值であり、内肛門括約筋切除術を施行、難治性 便秘の改善を認めた。内压桧查正常例では精神的要因 や排便習慣に問題を有する㱏例すあり保存的治燎を原 則としたが、偽性腸閉墨例では結腸重全摘を行つた。 直腸红門部器質性病变を有するるのとして襀唯性疛万

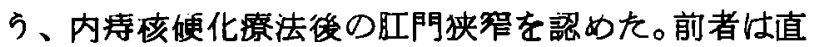
腸肛門反射(-)、ARP 2.2mmg，ASP 42mmig 之内肛門括䄪 筋㙨能の発絶を認奴為人工肛門を造設、後者けFer一 guson 法で狭篟部修復を行つた。巨大直踼を伴わない 巨大結腸例 2 例《旼治性便秘怔あり、S 状結腸軸捻転 を併発した。内王确歪は正常でありS状結腸切除を行 つた。「結論」巨大結湯例の手術の選択に肛門機能検 查は必要と考えた。

324 排便障害を伴う直腸肛門疾患の病態生

理および外科治療

南勢町立病院外科

○天野信一

排便障害を伴う直腸肛門疾患、直腸脱 (RP)、粘膜脱症 候群(MPS)、直腸瘤(RC)の病態を直腸肛門内压、超音波 排便造影加ら検討し、外科治療に応用した。

対象および方法: RP 30例(Tut t l e 分類 I 度 7 例。II度18 例、III度5例)、MPS 6 例，RC15例を対象とし、直腸肛門 内王湘定では直腸肛門静止圧、直腸肛門反射、直腸眝留 能を直腸内超音波、排便造影では努責、排便時の画像を ビデオ装置に記録コマ送り再生し、検討した。

結果と治療成績 : RP Tut tle 分類 I 度では直腸肛門 全層の滑りか主因と考え、4例に三輪一Gant 法を行い RPTuttle分類I度では努責時にcul de sac化したダ グラス窝に腹殴かかかり腸重積をきたすととによると 考え、13例に経腹的直腸後方固定術にダグラス窝を浅 くするSudeck変法を用い、肛門管内圧の低い3例に 挙肛筋縫縮を併せ行った。MRS.RCの成因はそれぞれ 直腸前立腺中隔、直腸䐦中隔の脆弱性によると考元、経 肛門的に直腸前壁筇膜の檤縮強化を行い、膀胱㿔、子 宮脱など骨盤内臟器下垂を伴うRC7例飞経腹的骨盤 底補強術を行い、いずれも排便異常の改善を認めた。
東京慈恵会医科大学第 1 外科, 神奈川県得生看護専 門学校付属病院外科 1)，神奈川県立厚木病院外科 2) ○藤川亨 . 片山隆市, 穴沢貞夫 , 桜井健司 岡部紀正 ${ }^{1)}$. 斎藤玻瑠夫 ${ }^{2)}$

当科および関連病院が経験した直腸脱手術症例は 17 例である。17例に計25回の手術を施行した。その術式 は，Tiersch 法10回，Gant -三輪法及びTiersch 法併 用 4 回，Gant-三輪法及びTiersch 変法併用 3 回，開 腹直腸剥離挙上仙骨前固定術 3 回 。開腹直腸剥離挙上 仙骨前固定術及び S 状結腸切除術 3 回である。そのう ち再発例は17例中 4 例であり. Tiersch 法またはGant 一三輪法及びTiersch 法併用を施行した 3 例䎲合計 6 回の再発及び開腹直腸剥離挙上仙骨前固定術を施行し た 1 例に再発をみた。 4 例中 3 例は，Gant-三輪法及 びTiersch 変法を施行し，良好な成績を得ている。

Tiersch 法は用いた銀線が離断してしまうことがあ り，再発し易く，リスクの高い高龄者にのみ適応が ると思われる。一方，開腹直腸剥離挙上仙骨前固定術 は再発面からは効果的な手術であるが，術後高い頻度 で, 便通異常がみられた。

326

の検討

松島病院大腸肛門病センター

○鈴木和徳，松島誠，中村 清，田中良明

ホワイトーッド手術 (WH手術) は種々の後障碍の ために次第に行なわれなくなって来ている。以前に了 けたこの手術のためにホワイトヘッド肛門 (WHA) となっている症例の最近の消長を検討した。昭和61年 から平成 2 年までの 5 年間に当院で手術したWHAは 238例であった。年令は平均59才。同時期の全肛門入 院手術症例 19,700 例の $1.2 \%$ であった。WH手術を5 けた年度は昭和15年から昭和62年にまで及んでいるが， 昭和 30 年前半より昭和 40 年後半までの 20 年間が厌倒的 亿多く76\%の181例が手術されている。年令は平均 33 才。症状は粘膜脱, 出血, 粘膜分泌, 括約不全, 肛門 狭窄などである。WH A の手術は症状により術式が選 ばれるが, 全環状切除 S S G 65例, 部分環状切除S S G 61例, 結禁切除71例, 結禁切除 S S G33例, その他 8 例を行なった。術後入院期間は平均 11 日間であった。 WH A は最近の 5 年間では未だ減少傾向がみられない。 WH手術の障碍を肛門内王測定によっても検索した。 
関西医科大学外科

○高田晃平，佐藤正人，杉浦 希，川西 洋， 真田俊明, 辻 正純, 浜田吉則, 日置楀士郎

小児頚部腫窗は多種多彩であるが、先天的なものが その多くを占める。今回我々は最近 15 年間に経験した 甲状腺疾思を除く小児頙部腫瘤36例を再検討し，とく に治癔上の問題点について考察した。36 例の内訳は，

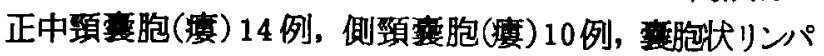
管腯 4 例の他, 気管支原性事胞, 異所性唾液腺などで

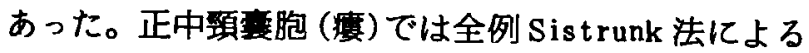
堑胞, 瘦孔周囲組織を含めた摘出術を行ない再発例を 認めない。側暊震胞(度)は 1 例を除いて第 2 鳃溝性で全 摘により再発例はない。售胞状リンパ管腯は年長览 の単房性例に亳胞の全摘が可能であったが。残る 3 例 はいずれも新生児期から呼吸困難を初発とする多房性 例で, 全摘は不可能であり，遗残霆胞に対し，OK432 局注を施行した。うち 1 例は。術直後に呼吸不全にて 死亡した。残万 2 例は局注療法と手術療法を併用し現 在も治療中であるが，経過中に繸隔浸潤や舌への浸潤 発育などを合併し、開胸手術や舌縮少術など多岐にわた る手術を要し、各種治療法の選択、時期について今後 の課題は多いと考えられた。

328 小児重胞性肺疾患の治経維

鹿児岛大学医学部小児外科

○野口壁幸，秋山洋，高松英夫。田原博幸、 福重隆意，安達康雄，加治建，下野隆一

1984 年 4 月以降当科において手術を施行した小 児の毫胞性肺疾患は15 例であった。费の内訳では 気管支性肺算胞 5 例、肺葉外の気管支原性素胞 2 例、 conenital cystic adenomatoid malformation ( C C A M ) 2 例、肺胞性肺喜胞 1 例、肺分画症 1 例で、最

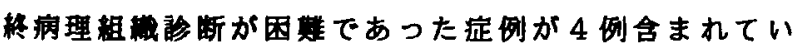
た。年哈は 4 日から 14 歳であり、男女比は $9: 6 て ゙$ あった。主症状は呼受器怒 10 例、呼吸困䢄 2 例、

胸痛 1 例、症状 2 例であった。画像診断法としては 胸部単純X楾写来、C T、MRI等を行なったが、肺 血管の走行、大助脈からの異常的脈の有無の㛟索には digital subtraction angiographyが侵が少なく小 児には有奻な㛟㚗法であった。病理組織診断が困難で あった症例のうち 1 例は病变部肺葉からの茺流脈が 下大静脈へ流入しておりScimitar症候群の筑政に入る ものと思われたが、他の 3 例は気管支の拻張を主体と する病变に资症性の变化が加わって䜌飾されており診

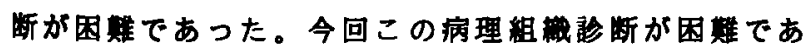
つた 4 例の站断を中心に若千の考察を加え報告する。
隔膜ヘルニアの4症例の検討

高柣病院 小巟外科

○家永徹也、岩村喜信、前田貢作、山本哲郎

術後患側肺の拡張不良を呈した重症横隔膜へルニア の4例を経験し、若干の考察を加え報告する。 4症例すへてに生直後よりチアノーゼを認め横隔膜へ

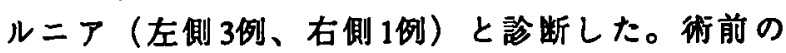
$\mathrm{AaDO}_{2}$ は4例とも500 $\mathrm{mmHg}$ 以上であり生後20時間以内 に手術を行なった。手術所見では全症例に患側肺の著 明な低形成を認めた。1例では術直後にECMOを使用し その後47日間の人工呼吸管理の後離脱できた。2例は 109日、19日の人工呼吸管理の後、離脱できた。残りの 1例は人工呼吸より離脱することができず肺炎のため 生後89日目に死亡した。これら4症例は術後の人工呼吸 管理中に患側肺の拡張が得られず健側肺の過膨服を呈 した。

救命しえた3症例は現時点では生存しうろ限界と考え られ、術後の陽圧呼吸により健側肺の過膨脹をきたし た。術前術後管理には長期の肺機能を考虑し肺の Barotrauma を最小限にする工夫が今後の課題と考えら れた。

小児悪性間葉腫の 2例

邚谷粉合病院外科

神谷保廣、上田悠久、佐藤幹則、寺田順二、浅野実樹、 三島晃、竹内寧、大久保憲、宇佐見詞津夫、小谷彦藏

稀な小児悪性間葉腫の 2 例の治療経過を報告する。 【症例1】10ケ月、男児。主訴 : 会陰部の無痛性腫慮。 腫場は後部尿道を後方へ王排狭窄し、球部尿道から骨 盤腔一達していた。尿道を温存し球部以後の腫瑒を残 し摘出した。横紋筋肉腫（胎児型）を主体とし、軟骨、 血管肉腫成分が混在した。術後 VAC 療法と放射線療法 を行い現在術後 5 年を経過し再発なく健在である。 【症例 2】4歳、女児。主訴：下腹部の有痛性腫瘤。 腹膜刺激症状、貧血の進行を認め緊急開腹術を施行し た。腫韵は仙骨前面より骨盤照を占执し正中部で穿破 していた。繾合止血し終了した。腹腔内容物から横紋 筋肉瘇 (胎児型) と診断した。Pulse VAC 療法 4 週後 腫瘾を触知しなくなり 12 週目再手術を施行した。後 腹䐉原発で、軟骨肉腫と未分化肉腫が混在し悪性間葉 凬と診断した。術後5ケ月再発を認めない。

【結語】要性間葉腫は横紋筋肉腫成分を含むことか 多くこれを標的に化学療法を行ない、腫瑝の縮少後完 全摘出をはかることが選択される治療と思われる。 
331

新しい修復法

両側広背筋 $\mathrm{V}-\mathrm{Y}$ 皮弁による髄膜瘤の

東邦大学形成外科, 同脳神経外科*

○林 明照, 丸山 優, 清木義勝*, 柴田家門*

髄膜瘤の治療は，早期に創を血行豊富な組織で閉鎖 し，髄液漏や髄膜炎を予防することが大切である。わ れわれは，中〜巨大背部欠損に対し両側広背筋 $\mathrm{V}-\mathrm{Y}$ 皮弁による修復法を考案し，満足すべき結果を得てい るので，若干の考察を加え報告する。

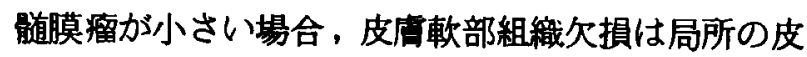
弁や筋膜皮弁で被覆できるが, 中等度から巨大な欠損 ではその治療に難㸃することがしばしばである。これ に対し，従来より逆行性広背筋皮弁や両側広背筋皮弁 などが用いられているが, 前者は被覆できる久損の大 きさに限界があり，後者では両側側胸腹部に減張切開 が必要であり，整容面で大きな問題を残していた。ま た，両側広背筋＋大殿筋皮弁による再建法は非常に有 用であるが，手術侵譬が過大となるのが欠点である。

両側広背筋 $\mathrm{V}-\mathrm{Y}$ 皮弁は，巨大な欠損であ血行の安 定した筋皮弁で被覆でき，ドナー部むV－Y法により 容易に一次释縮が可能であり，低侵襲で整容的にあ優 れた方法である。また広背筋の機能を温存できること 屯利点の一つである。

332

精神的ストレスおよび性格的特徵が主

たる成因として考えられた小児胃漬場穿孔の 1 例

国立呉病院小児外科

○山東勤弥, 八木 誠

小児の消化性漬瘍は近年增加の傾向にあり，その成 因として小児を取り巻く社会環境の複雑多用化に伴与 ストレスと本人の性格的特街の関与が指摘されている。 症例は 8 感の男児。来院時顔面苦闢状, 腹部は全体に 板状硬。腹部単純レ線上，横隔膜下に f ree a i r 認 めたため，穿孔性腹膜炎の診断下に緊急手術を施行し

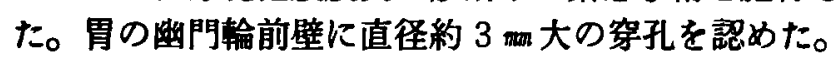
患児の年齡を考虑して, 穿孔部切除術, 幽門形成術ま よび選択的近位迷走神経切断術を施行した。術後経過 は良好でった。術後行なった上部消化管造影かよび 内視鏡検査にてる特に異常所見なく，血清ガストリン 値 2 回(術後 21,28 日目)の湘定て，49,69pg/ml と 正常值内 (37-172 pg/ml)であった。家族歴て，母親か 十二指腸謴場の既往がある。両親か不和のため現在別 居中で，患児と同居している母親が抑圧状態による Kitchen drinker て精神科で治䖍中であった。そのた め患児の心理テストを行なった結果，患児は欲求不満 の解消を自罚的に解決しょうとする傾向が強く，てれ か胃潰㷎の主たる成因として考えられた。
333

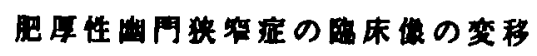

東京意患会医科大学第一外科

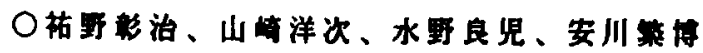

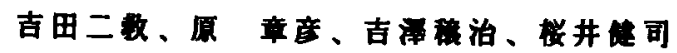

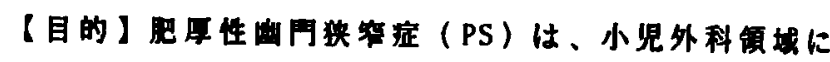

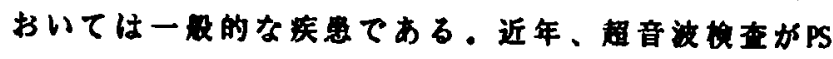
の馀断に落入され、また小児科医のPSに対する者え方 も变化したと思われるのて、PSの林像が变程したか 否か松村した。

【対象】1970年から1991年4月までに手待したPS息児 77 を前期11年 $(n=39)$ と传期 10 年 4 力月 $(n=38)$ に区別

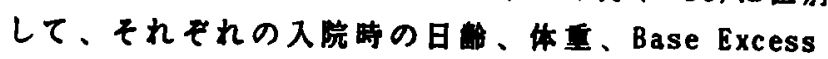

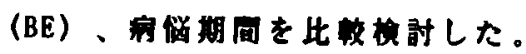

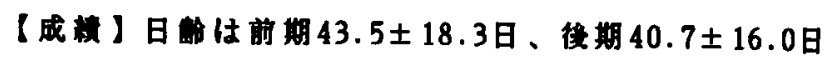

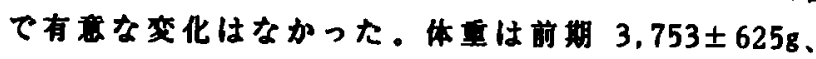
接期 $3.830 \pm 575 \mathrm{~g}$ 、BEは前期 $+2.1 \pm 4.8$ 、得期 $+4.3 \pm$ 6.4 、角珰期间は前期 $21.7 \pm 12.7$ 日、後期 $22.2 \pm 14.9$ 日でありすべて再群间に有意差は侭められなかった。

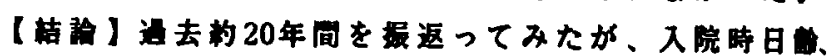

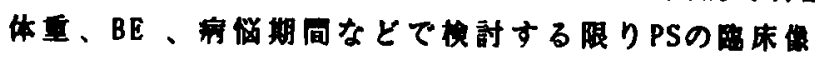
の变移はとくに琶められなかった。

334 腸回転異常症晚期発症例の検討

聖マリアンナ医科大学第 3 外科

○川口文夫 . 中田幸之介 。藤岡照裕 , 北川 博昭, 江並朝猛, 桑原幹夫 脇坂宗親, 山手昇

過去16年間に43例の腸回転異常症を経験した。この うち生後 1 加月以降の晚期発症例14例(32\%)について検 討を加えた。年齢分布は2 2 月 12歳で男児11例 ，女児 3例であった。重症心奇形,内臟逆位を伴い術後腎不全 で死亡した 1 例を除き全て生存している。新生児期発 症の16例(72\%)が術前診断されていたが、晚期発症例で は術前腸回転異常を疑ったものは 5 例(35\%)のみであ った。1例は腸重皘を疑い，注腸検查により腸回転異 常と診断し待期手術としたが，軸捻転を伴っていた。 1 例は 1 か月続いた血便の後最終診断した。他疾患の 診断で開腹されたものは 7 例で内訳は胃軸捻転，急性 虫垂炎，疮着性腸閉塞などであった。中腸軸捻転は12 例(85\%)に伴っており，Ladd手術は11例に行われた。 また重篤な腸管壊死に陥った 2 例は Second look operation としたが, 腸管切除となった。 〔まとめ〕腸回転異常症は軸捻転による腸管壊死を最 小限に留めることが重要であるが，晚期発症例の場合 術前診断に難渋するととが多く注意を要する。また術 前軸捻転を認めない場合も予防的手術が必要と考える。 
335 巨大西腫状胎便性腹膜炎 5 例の経験

北里大外科. 小览科

○椐田咲美乃，古田一德，石田和夫， 柿田章. 小口弘毅“

胎便性腹膜资は胎生期に胎便が腸管外飞漏出するこ とにより起こる腹膜资であるが，時に腹腔全体に仮性 亚腫を形成することがある。この様な例の報告は比較 的稀であり，また治療方針について㦈論のある疾患で ある。我々はこの巨大露腫状胎便性腹膜炎 5 例を経験 したので若干の考察を加え報告する。

5例とも本知患の特徵である生直後よりの著明な腹 部膨满と呼吸障害をきたしていた。経胵分娩で婏出困 難のため腹腔内に大量出血を来し，失った 1 例を経験 した。最近の 2 例は出生前診断され帝切で婏出した。 病斨は全例腸閉鎖を伴い，穿孔部は震腫内に開存して いた。手術方針は一期的に行らかどうか等議論のある ところであるが，我々のこれまでの経験から一期目は ドレナーシ十腸㾇とし， 2〜3ケ月の栄美管理の後，

二期目で根治手術を行万方針が適当と思われた。予後 は婏出時大量出血の 1 例と超未熟児の 1 例の 2 例を失 い. 1 例は根治衡待機中である。

$\mathrm{X}$ 線診断上も興味ある所見が得られたのでこれも併 せて供覧する。

336

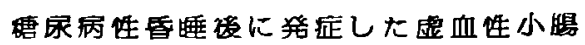

实应の 1 例

香川医科大学小児外科

○佐滕恭久、戸谷拓二、造辺泰宏、土岐新、

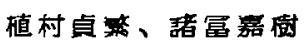

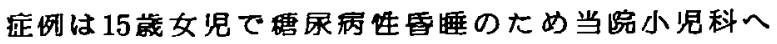
繁急入院となった。インスリン愿法により入院 3 日目 に意識レベルは正常化したが、4 日目より整度の上腹 部痛が出男し、24日目より呕吐が出娚した。46日目に 行った上部消化管造影で驾腸の狭窄が発見され当科稆 介となった。関腹により、トライツ洓から肛門側 63 cnと75cmの 2 力所に㹨䔄をみて、狭窄部を含め空腸を

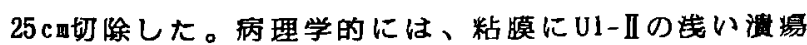
形成と全序にわたる高度の線維化、血管増生、炎症紐 盷の漫潤、槽造の破㯰がみられ、一部にへモジデリン

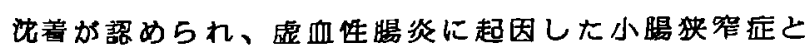
診断された。糖尿病件血管障害を背景に、昏睡に伴う ケトアシドーシスと眖水による血液粘稠度の上昇、血 小板磁集能の亢進、ショックなど超因として、觑血 珄小腸狭窄へ進展したと考えられる。
337

\section{高知県立中央病院外科}

○長田裕典, 間島國博, 徳岡裕文, 近藤庋二

小児の腸重積症において先進部に器質的病变を認め る頻度は $10 \%$ 以下である。我々は回腸腺筋喱によるき わめて稀な腸重程症を経験した。症例は 3 嵅女児。腹痛,

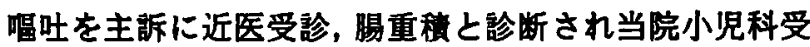
颜した。バリウムによる整復を試みたが不可能なため 钼血的整復俦を施行した。回腸一回腸一結曶の五简性 重糟をHutchinson 手技により整復した。回晹末端よ り $40 \mathrm{~cm}$ の回腸腸間膜対側に小指頭大の腫溜があり，先 進部之なっていた。腫溜を含めて小腸部分切除を行っ

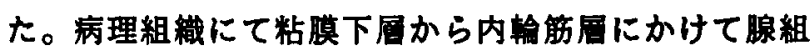
織と平滑筋線維の增生よりなる腺肪腫と竝断した。小 晹腺筋腫の報告は現在までに15例あり，殆との应例が 腸重積を契機に発見されている。本例も含めて若千の 考察を加えて報告する。

338 当院における小児腸重糟症の释䀫 長野赤十字病院小児外科，日赤医磨センター小児外 科*

○北原一郎, 清水公男, 寺田 克, 大倉充久 ・

目的：当院は長野市の二次救急病院である。救急疾 患の中で小児外科の代表的疾患である腸重皘症につい て、当院における治療の現状を明らかにする。

方法：当院が長野市の中心部より移転した1984年5月 より1991年4月まての 7 年間に、腸重積症のために治㞠 した症例を対象とし、年榆、性別、発症加らの時間、 症状、治法、再発等について梌璟した。

成綪：対象とした症例は男39例、女18别の計57例で、 年柃は 3 力月から 9 歳（平均19力月）、注晹造影を行 って晾断した後すぐ整復を試み、50例(88\%)は整復で きた。発症加ら24時間以上経過した症例は12例あり、 3 例が手術に至った。注腸整復が武みられ、その後紹 介された症测は 8 例であり、このうち 3 例が手術を要

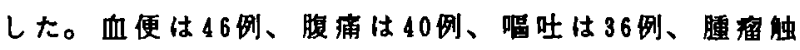
知は35例に㴔めた。手術は、整復不能な 6 例之 4 回再 発した 1 例に施行した。小腸ポリープ、渴管蕞胞、晹 管穿孔が各 1 例にあった。再発は 9 例に計22回発生し

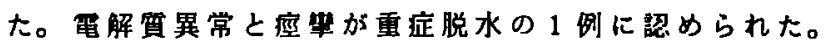
結論：患児の状態により再整復を武みる価值はある。 
術後イレゥスは、開腹術の合併症の中であ大きな課 題の一つである。小児においては、原疾患の特異性や、 体格が小さく腹腔が狭いととなどにより、治療は困難 で、再開腹を余儀なくされるととも少なくない。1983 年 4 月〜 1991 年3月まで当センターで経験した開腹術 後イレゥスは41例である。そのうち保存的治療は15例、 手術治療は26例であった。手術例のうち 9 例は絞扼性 イレゥスで、更に 5 例は腸切除を要した。原疾患は、 玡孔性虫垂炎が 8 例之最む多く、Hirschsprung 病 6 例、 胆道閉銷症 5 例、その他神経芽腫、腸重皘などであっ た。開腹術からイレウス発症までの期間は 3 日〜 4 年 6 ケ月、平均 154 日で、約半数の 21 例は術後30日以内 であった。保存的治療での減王期間は 1 日〜 11日、平 均 4.2 日で、手術治療は 0 日〜 7 日、平均 2 日間の減 匤の後行っている。41例のうちイレゥスの再発が13例 に見られたか、9例は保存的治療にて軽快し、4例は 手術を行った。保存的治療の際、通常の胃管、イレゥ ス管の他、我々の考案した long tubeを用いているが、 その実際についても報告する。

340 開口異常の検討

聖マリアンナ医科大学第 3 外科,

同東横病院小児外科*, 同横浜市西部病院小児外科** ○藤岡照裕, 中田幸之介, 桑原幹夫, 江並幹猛, 北川博昭, 川口文夫**, 脇坂宗親**, 山手 昇

【目的】胆道開口異常を伴った先天性十二指腸閉塞症 を比較的高頻度に経験したので検討結果を報告する。

【対象・方法】対象は1978～90年の13年間に経験した 十二指腸閉塞（閉鎖，狭琵，十二指腸重複症）27例で ある。臨休経過または手術所見より胆道開口異常之診 断した症例を検索した。

【結果】27例中胆道開口異常が認められたのは11例(41 \%) であった。そのうち十二指腸閉鎖部の口側と肛門側 の 2 力所に胆道開口を示した症例は 7 例であった。膜 に胆道の開口が見られた膜様狭窄は 3 例であり， 1 例 は総胆管拡張症を合併していた。豪腫状十二指腸の重 複による十二指腸閉塞例では共有する十二指腸壁内を 胆道が走行し豪腫状十二指腸壁に開口していた。

【ま之め】先天性十二指腸閉塞に胆道開口異常を合併 する頻度は 4 割と高く, 手術に際しては胆道開口異常 の存在を常に疑い，胆道または開口部の損傷を来さぬ よう充分な注意が必要と考えられた。
341

素の分析

先天性胆道拡張症における胆汁中脺酵

埼玉県立小児医療センター外科

○有園さおり, 今泉了彦, 平田彰業

寺倉宏嗣, 尾花和子

はじめに：先天性胆道拡張症の成因は、膵、胆管合 流異常に上ると考えられているか、幼若児例では造影 困難で、胆汁中のアミラーゼ活性も低值であるため、 合流異常ははっきりしないととが多い。胆汁中のトリ プシン,リパーゼあ併せて測定したとてろ、上昇を認めた。 対象：当センター開院後 8年間に経験した 27 例を対 象とした。新生児 2 例、6 个月以下乳児 2 例の胆汁中了

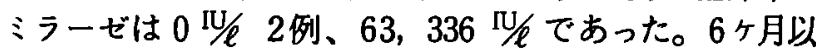

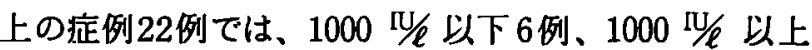
14例、未検 4例であった。胆汁中のアミラーゼが全く検 出されなかった例であ、リパーゼ85年、トリプシンは $900^{\mathrm{ng}} \mathrm{m}$ 尚以上と明らかな逆流を認めた。

結論：先天性胆道搪張症では、胆汁中アミラーゼは 異常高值を呈するととが多いが、幼若児例では上昇し ないととが多く、膵、胆管合流異常説には議論のある ところであるが、アミラーゼ以外の膵酵素を測定する ことにより、逆流を証明し得るとともあるので、今後 てれらの脺䣼素の分析あ重要であると思われる。

342 くり返す嗄击の原因となった小児の胆

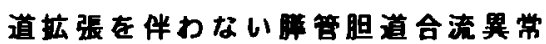

金沢医科大学小児外科

○䁫外茂次、河事美幸、小沼邦男、伊川筑道、北谷

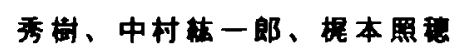

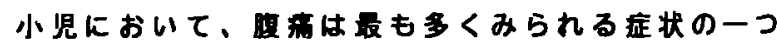
でるが、くり返す喂薄の原因が胆道㹡張を伴わない

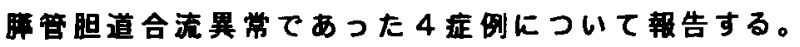

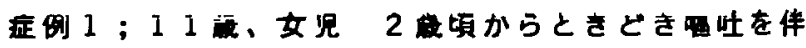

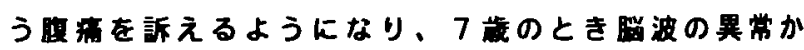

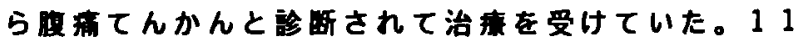
藏になって禹アミラーゼ血症がみられ、ERCPによ

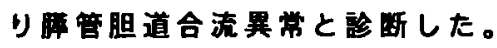

症则 $2 ； 2$ 戴、女児症例 $3 ; 9$ 歳、女児

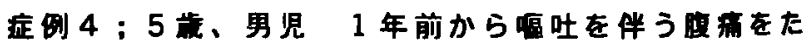
ひたひ訴え、数䇋設で精㚗を受けたが異常なしといわ

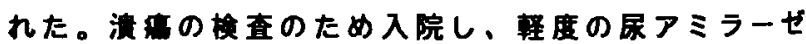
の上昇から、ERCP民行い合流異常と詓断した。

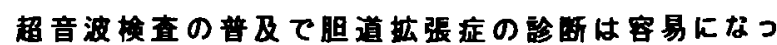
たが、桩張を伴わない合流異常は腃症状がおさまっ

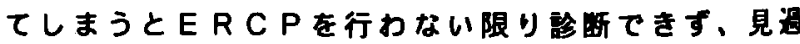

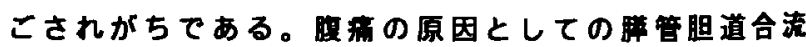
異常の存在について知っておくことが重要である。 
343

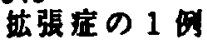

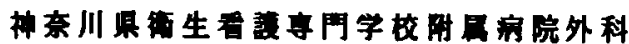

東京意恵会医科大学第一外科

○吉田二数、岡部㲹正、西田婎、山崦洋次※ 棪井践司米

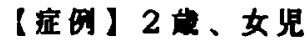

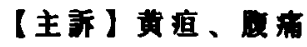

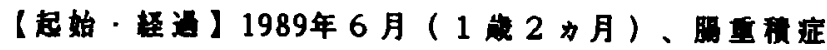

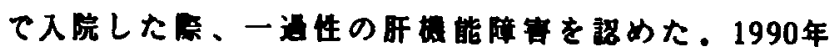
5月8日頃から黄值、蕅藕が出現し、5月11日当院小

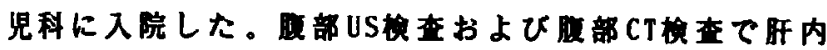

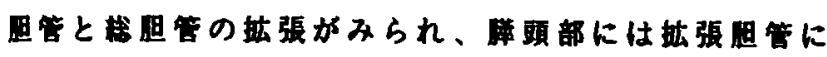

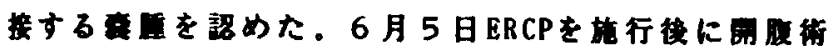

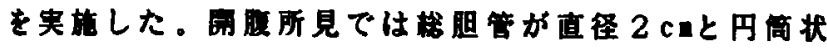

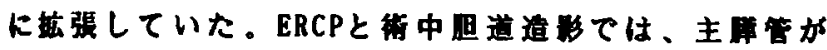

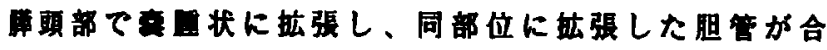

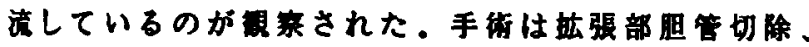

所管空雷的合 (Roux en Y) を行った。

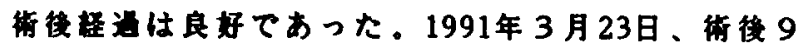
カ月目に再度ERCPを施行したが、主管の至状拉张 は牫存していた。

344 小児慢性脺炎に対する longitudinal pancreat i co je junos tomy の試み

福岡市立とども病院外科，九州大学小児外科*

○大神浩, 長㥓 彰, 豊原敏光, 山内 健 ${ }^{*}$

小児慢性膵炎は本邦において未だ報告峢が少なく、 診断、治潦面においても検討の余地が多いと考えられ る。今回巨大膵石を伴う僈性脺炎の 1 例について報告 する。

症例は 9 才男児。主訴は発熱と榎痛で、高アミラー ゼ血症を指摘され受診した。

諸觎查にて主膵管の著明な拡張と膵石を認めたが、 総胆管は正常であった。手術所見では、著明に拡張し た主膵管と膵頭部を主とする多数の膵石の存在を認め た。睟管切開膵石除去後 longitudinal pancreaticoje junos tomy を施行した。膵組織所見では小葉間、小 葉内の䋐維化が著明で慢性膵炎の像を示した。術後経 過は良好で膵胆管合流異常は認められなかった。

近年画像診断の并用により膵炎の診断仕比較的容易 になったか、慢性膵炎の病因㤌種々でその形態仕多様 であるのが特徴である。膵管拉張、膵石形成合并例で は choledochocele、睟腫などとの鑑別が必要であり、 明道系正常所見で結石を認める应例では、1ongitudinal pancreat i co je junos tomy が有堵である。
345

膵管吻合の経跧

金沢医科大学小児外科

○河野美幸，伊川属道，中村紘一郎，梶本照㯖

外侮性体部完全断裂に対し膵管吻合を行ない良好 な結果を得たので報告する。

症例は 9 藏男児, 自転車のハンドルで腹部を打撗。 受偟 8 時間後に入院。超音波，CTで勝外侮と診断し， 受侮約24時間後に緊急手術を施行。䬶体部にみられた 凝血塊を除去すると膵は完全に断裂しておりり，直下に 脾静脈を認めた。膵管断端の挫减が両侧ともほとんど なかったので，膵管吻合を行なった。萃管にステント カテーテルを留距し，これを脺尾部を経由して腹腥外 に誘洋した。他の蔵器には損倁はなかった。術後11日 目にカテーテルから变管造影を行ったが, 模管吻合部 の湍れや猝管の拡張は認めず，カテーテルを抜去した。

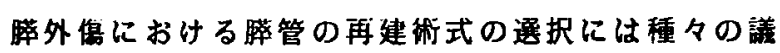
論があり，特にMartin法は維合不全の危除性が高い故 に敬遠されがちである。しかし，我々の症例のような 膵管の挫減加少ない場合に，膵管吻合は選択されるべ き方法と考える。またMartin法と異なりカテーテルを 满尾部より体外に引き出した我々の方法は，十二指腸 に侵缼を加える必要がなく，传れた方法と考えられる。

346

乳児痔瘦の治療一新生児期初発例之

乳児期初発例の比較

大阪大学小児外科

飯干泰彦, 辻尚人, 岡田正

過去9年間に当院を受診した乳児庤㢈83例につき。 臨床像を中心にretrospectiveに検討した。全例男児 で，新生児期初発例（25例）はすべて乳児期に当院を 初診しており，乳児期初発例（58例）の初診時期は。 乳児期 43 例，幼児期 11 例，学童期 4 例となっていた。 新生坚期初発例の瘦孔数仕，1個 $60 \%$ ，2個 $28 \%$ 。 3個以上 $12 \%$ で，86\%（37力所中32）が側方向で， 乳児期初発例は，1個59\%，2個 $28 \% ， 3$ 個以上 $13 \%$ て 81\%（93力所中 75）が側方向にあった。

不明・治療中の症例を除き，新生児期初発例は， 21 例中 20 例が保存的療法にて生後平均 9.5 力月に治疾 し得た。乳児期初発例は，44例中35例が保存的療法に て生後平均11.5力月に治䈍し，9例は生後平均5年 $2 力$ 月に手術となった。手術適沁は，幼児・学童期再発例 4例，長期・難治例2例，巨大脹渴例1例，その他3例で, 術式は瘦孔摘出術 8例，瘦孔切開術 2例であった。新生 児期初発例では，治瘜の遥延・再発例がなく，手術を 必要としなかった。以上の結果について述べる。 
347 小児外科疾患に対する，ポリエチレン

グリコール電解質液を用々た腸管洗浄法の経験

東京大学小児外科

○金森 豊, 中條俊夫, 橋都浩平, 河原崎秀雄, 宇津木忠仁，田中 潔，杉山正彦

目的：ポリエチレングリコール電解質湤を用いた腸管 洗浄法は，小児に対する報告例はいまだ数少ない。今 回我々は小児外科疾患19例に対して本腸管洗浄法を応 用したので報告し，適応上，施行上の問題点について 考察を加えた。

方法・結果：大腸手術前, 大腸鏡検査前, 悪性腫煌化 学療法前, 肝性昏睡患児, 飞本腸管洗浄法を応用した。 投与方法は, 検查, 手術前日に，ポリエチレングリコ ール電解質液を $30 \mathrm{ml} / \mathrm{kg} / \mathrm{hr}$ の速度で, 経口または経悬 胃管より投与した。腸洗净の効果は，不十分な洗浄に 終わった 2 例を除いて良好であった。また重篤な合併 症は1例もなかった。施行上，年長児への投与が問題 で，経口投与を優先させたが，充分量の领用が困難な ことが多く，程悬胃管よりの投与す困難があった。 結論：ボリエチンングリコール電解質液を用いた腸管 洗净法は小児です有用である。しかし，小児での適応 上，施行上の問題点すありこれらにつんては今後の検 討が必要である。

\section{8}

小児の排便障害の診断と治療

一特にヒルシュスプルング病と巨大直腸症につんて一 市立札幌病院外科，市立札幌病院救急部 * 北海道大学第一外科 *

○小池能宣，秦 温信 *”, 中西昌美, 手戸一郎 * 佐々木文章 $*$, 内野純一 *

小児におんて排便障害 (主に便秘) )をたす疾患の うち,外科的治療の奏功するHirschsprung病および巨 大直腸㱏について診断, 手術術式, 術後成績などにつ らて検討し知見を得たので報告する.

1955 年より 1990年まて上記2施設にて経験した agan glionosisを疑わせる症状を示した小児症例は 129 例 て，注腸，直腸肛門内圧娭查，直腸生検などて 92 例 かiHirschsprung 病，37 例が慢性便秘症 (巨大直腸 あり 24 例，なし 13 例) と診断された. Hirschsprung 病には，77 例に根治術 (Swenson 5,Duhamel 33， Soave 27, Martin 3, 内括約筋切開 5, その他 4）を 行々，巨大直腸を伴う慢性便秘症には，11例に Sphinctero-myectomy and plasty (SMP)を行っ た. Hirschsprung 病㭪挠，SMP戈後の遠隔成䋶は 各々約 $80 \%$, 約 $72 \%$ に正常排便を認めた.

小児の排便障害の診断には注腸，直腸肛門内圧, 直 腸生検の各検査の組み合わせが有用で, 巨大直腸を伴 う慢性便秘症にはSMPは有奻な方法と考えられた。
349 年長児のHirschsprung 病の診断と治療 埼玉県立小児医療センタ一 外科

○寺倉宏嗣, 今泉了彦, 平田彰業, 星花和子, 有園さおり

Hirschsprung 病は、新生児外科の代表的な疾患であ り、80〜90\%はは新生児期に発症する。しかし少数例で おるが、年長児に排便障害を主訴に発見されることむ ある。今回我々は、当センターにおいて経験した、年 長児のHirschsprung病症例について、その臨床像及び 治療法について検討した。当センターにおいて経験し た Hirschsprung病症例は現在までに54例で、そのう ち 13 例が 1 才以上の症例で、最年長は 15 才でおっ た。持続する便秘のため、ほとんどの症例が緩下剂 や浣腸などの内科的治療をうけていたが症状の改善 がみられず、便失禁、腹満、腹痛などの症状が出現 し来院した。診断は、バリウム注腸にて、著名な megacolon や megarectum が確認され、その後直腸肛 門内王検查、直腸生検を施行した。手術術式は、4 例が内括約筋切開のみで、残り10例に対しDuhamel池田手術を施行した。内括約筋切開の 1 例は、排便 困難が続き、近くDuhamel-池田手術を行う予定で ある。残る 12 例は、自力排便が可能となり、長年の 病苦より解放された。

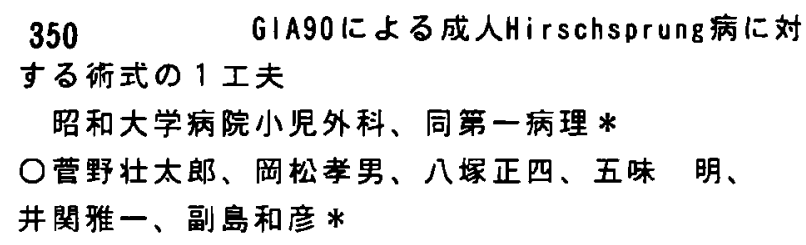

我々は、19才女性にみられたHirschsprung病に対し てG|A90によるDuhamel一池田法根治術を行なう機会を 得たので、その術式とエ夫について報告する。

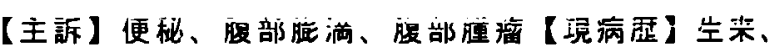
便秘であったが、中学生頃より腹痛を伴うようになり、 最近になって腹部腫瘾を認め、当科に入院した。各検 査よりHirschsprung病と診断され、一期的根治術を行 なった。【術式】腹膜㽗転部より約 $10 \mathrm{~cm}$ 口側の直腸 (Rs)にcaliber changeを認めた。口側結腸をpull throughした後、肘門側よりG|A90を 2 本㧴入し、隔壁 を切除。さらに腹腔側からも2本抙入し、中隔を切除 し、池田式 Z型吻合術を行なった(出血量 $362 \mathrm{ml}$ )。術 後柽過は良好で、現在全く便秘を全く認めない。

成人例では小児とは異なり、GIAによる阿壁切除は 困難とされる。我々は、G1A90を腹腔、肛門側から各 本ずつ、計 4 本用いることで隔壁を切除し、吻合し得 た。かかる操作により切除標本としても資することが でき、本方法は有用であると思われた。 